\title{
11
}

\section{Aftermath: Britain's Reaction to the Failure of the Amherst Embassy}

The Amherst Embassy's fate was announced to the British public by The Times on 10 May 1817. The Company ship Prince Regent, newly arrived from India, had met the General Hewitt at St Helena and brought the news that 'The Embassy has wholly failed, and the presents which were to have been the pledge of amity and intercourse have been returned so we have not lost all' (The Times, 10 May 1817). Some of the presents had been sold at Canton, but the bulk of them were returning to England on board the General Hewitt. Reasons for the embassy's failure were not yet known, but it was hoped that trade at Canton had not been affected. The General Hewitt's arrival in England was 'hourly expected' (The Times, 10 May 1817). The Times published an extract of a letter written by a junior member of Amherst's retinue five days later on 15 May that described the honourable treatment the embassy received on its travels through China to Canton. The English had enjoyed walks in the countryside due to 'a liberty rather taken than a liberty given' (emphasis in original); had travelled over 'a considerable portion of new ground, or more properly speaking water', and had received a 'very sulky' reception at Canton where the embassy was not saluted (The Times, 15 May 1817). An article published on 26 August 1817 contained some more details of the embassy, but a full account was not available until Ellis's (1817) journal appeared in British bookshops in late October. 
The importance of the Amherst Embassy in shaping British views of China in the crucial period leading to the First Opium War (18391842 ) is the subject of this chapter. While Staunton informed Morrison in a letter dated April 1818 that 'the whole question of this Embassy [in England] is now passing fast into oblivion', Amherst's hostile reception by the Qing court was important for providing new intelligence on Chinese officialdom and contributing to a reassessment of China that informed later British policy (see Hampton, 2009, p. 4). ${ }^{1}$ Henceforth, British reviewers in popular journals portrayed the Chinese emperor and his court as a barbaric Tartar horde and praised Amherst's firm actions in upholding British honour and the status of the British sovereign. Although the embassy failed in the short term in achieving its goals, its long-term significance remained and is traced here through references to it in the period leading to the First Opium War. Ellis's and Staunton's opinions were canvassed both at the time of debate over the review of the Company's charter in 1833 and also in the House of Commons in 1840 on the eve of British military intervention in China. The true legacy of Amherst's reception at Yuanmingyuan was to confirm the futility of further diplomatic initiatives to achieve British commercial goals in China and to promote the expediency of using force, if necessary, to achieve these aims. Such sentiments were shared by some American traders at Canton and stated bluntly by one trader, Isaac Bull, who commented later in 1840, 'The English may talk reason with the Chinese until the day of judgment, [but] the latter will not give them what they want without force' (as quoted in Miller, 1974, p. 98).

Amherst arrived back in England on 16 August 1817. Captain Maxwell sent a letter expressing 'the honour, the heartfelt pride, and gratification of being ship mates with Your Lordship for eighteen months' (Maxwell to Amherst, Ship Caesar, Isle of Wight, 16 August 1817, in BL IOR MSS EUR F 140/39). ${ }^{2}$ The Dowager Amherst wrote, 'Welcome! Thrice Welcome! To thy native land My Dearest, Dear Lord Amherst, \& your Dear Boy. How thankful I am' (Dowager Amherst to Amherst, 20 August 1817, in BL IOR MSS EUR F 140/39). The Archduke of Austria summed up the delight and relief of Amherst's friends: 'The joy I have felt in your safe escape outweighed by far that which the most successful

1 Hampton (2009) referred to the diplomatic space 'where knowledge of the Other is produced, where interest is weighed and gauged'.

2 Maxwell informed Amherst that his luggage was boarded on wagons and was on its way to his house in Grosvenor Street. Customs had mistakenly opened and inspected his bags, but they were due to be severely reprimanded by the collector, who had been attending church at the time. 
result of your Embassy or scientific enquiry would have given me' (John, Archduke of Austria, to Amherst, Vienna, 1 October 1817, in BL IOR MSS EUR F 140/39). Lord Morley was the only one of Amherst's friends who expressed doubt over his decision not to kowtow before the emperor, but these thoughts were accompanied by qualifications. His 'uninformed feeling' was that he would have 'complied with any ceremonial [and] ... would have gone in any state of fatigue or in any dress ... into the presence of the Emperor', especially when accompanied by Mandarin speakers able to explain the truth of the ambassador's appearance (Lord Morley to Amherst, Paris, 21 September 1817, in BL IOR MSS EUR F 140/31). But if Amherst had evidence of a 'generally hostile feeling', then he was 'right to refuse' (Lord Morley to Amherst, Paris, 21 September 1817, in BL IOR MSS EUR F 140/31).

Amherst's chief grievance was the contrast in his reception with that of Macartney's. Macartney had maintained that there were 'a considerable number of great people at Court who [had] expressed their being much pleased with us, and who wished that we had continued here longer' (Cranmer-Byng, 1962, p. 155). Rather than being received in an orderly and regular manner where the dignity of the Chinese emperor and the King of England had been maintained, Amherst's reception was marked instead by 'hurry and precipitation' (Amherst to Canning, 8 March 1817, in BL IOR G/12/197 (Reel 2) F 285). Amherst was offended especially with the removal of every mark of splendour and 'respectable appearance' of his embassy, serving to reduce it to the degrading appearance of one of China's meanest tributary vassals. His uncompromising stance in China, on the other hand, was praised in the highest circles of the British Government. The governor-general of Bengal, the Earl of Moira, wrote:

I am perfectly persuaded, and it seems the universal opinion here, that Your Lordship has gained more by your firmness than you could have done by any compliances with the arrogant proposition made to you. I do not speak merely as to the impression of the British character so worthily upheld by you. We are all convinced that for the Company's trade more advantage will flow from the anxiety of the Chinese to repair an affront which they apprehend may be seriously resented than could have arisen out of any Disposition infused into that Government by conciliatory submissions. (Earl of Moira, Calcutta, to Amherst, 13 April 1817, in BL IOR MSS EUR F 140/39) 
Staunton agreed with Lord Moira. He pointed out later in his privately printed memoirs in 1856 that, although the Amherst Embassy had been 'stigmatised as a failure':

It was practically, perhaps, the most successful of any that had ever been sent to Pekin by any European power; for it was followed by a longer interval of commercial tranquillity, and of freedom from annoyance, than had ever been experienced before. (p. 68)

This view was repeated by Davis in his later study The Chinese (1836/1851), where he stated that from 1816-1829 there was not a single stoppage of British trade at Canton apart from the incident involving the Topaze frigate in 1822, in which the Canton authorities made the first advance to a resumption of trade (vol. 1, p. 81).

Staunton's belief in the value of the moral example left in China by the Macartney Embassy applied also to the Amherst Embassy. Amherst's defiant stand and firm assertion of British values and honour in his dealings with the mandarins had achieved a more beneficial outcome for British interests than would have resulted from a mere ceremonial reception, 'had there been one', at the Qing court (p. 67). Davis was of the same opinion. Barrow, he pointed out, had observed that 'a tame and passive obedience to the degrading demands of this haughty court serves only to feed its pride, and ... the absurd notions of its own vast importance' (as quoted in Davis, 1836/1851, vol. 1, p. 77). Amherst's strong stand based on his advice not to kowtow, Staunton argued, had a most positive effect on the Cantonese authorities resulting in a peaceful period of trade with few interruptions until the late 1820s. It seems ironic that the Amherst Embassy was judged by some as achieving a more successful outcome for British interests than its predecessor.

However, the reaction of one of the missionaries at Peking, presumably Lamiot, to the reception of the Amherst Embassy at Yuanmingyuan was one of concern. Amherst had in his possession an extract of a letter which read:

Here [at Peking] it is much dreaded that the English will demand some satisfaction, for in truth, very unjustly have they been treated, and with great baseness. This may be attended with important consequences for us, and it will be well that we should be prepared beforehand. (Extract of a letter from one of the Missionaries at Pekin, n.d., in BL IOR MSS EUR F 140/38 (a)) 


\section{Reactions of the British Media to the Amherst Embassy}

In September 1817, the publisher John Murray wrote to Lord Byron informing him of his busy schedule:

I have just come to town for a few days and have my hands quite full-I am preparing two accounts of the unfortunate China Expedition including one by John M'leod and one by Mr. Ellis (Ld Buckinghamshire's son). (Cochran, 1922, p. 78) ${ }^{3}$

Attention to the Amherst Embassy in England coincided with the publication of books on the embassy in 1817 and 1818. Further interest is not evident again until 1821 when reviews of Morrison's (1820) account of the embassy were published. Staunton's English translation of the Chinese account of a Narrative of the Chinese embassy to the Khan of the Tourgouth Tartars in 1717 was also published in that year and reviewers made passing reference to the Amherst Embassy. The spotlight on the embassy resurfaced again in 1821 during the proceedings of an enquiry into trade with the East Indies and China before the Select Committee of the House of Lords.

The published accounts of the embassy, in particular Ellis's journal published in 1817 as intimated previously, confirmed Barrow's earlier views of China. Ellis's book was the first and acknowledged 'official' account of the embassy, and his views were significant in consolidating the first assessments of China to emerge from the Amherst Embassy. The American historian Stuart Creighton Miller (1974) has more recently summed up Ellis's contribution as one revealing:

The alleged pretentions and arrogance of Chinese officials; Chinese propensity for filth, lying, cheating, and cruelty; the primitive state of Chinese science and medicine; and the slavish adherence to customs-all were present. (p. 52)

Ellis portrayed China as a stagnant and dull country whose people suffered from a lack of freedom and progress due mainly to the oppressive rule of the usurping Manchus. A letter to the editor of the Asiatic Review in January 1818, signed with the nom de plume 'Yen Kwang', not only repeated

3 The letter continues that he also had 'Two novels left by Miss Austen-the ingenious Author of Pride \& Prejudice-who I am sorry to say died about six weeks ago’. 
these judgements but added that Chinese pride and self-sufficiency only debased them among other nations due to their ignorance and misguided belief that the "world is a plain with China in the middle surrounded by all other nations, kindreds, and tongues as tributaries'. While the experiences of both the Macartney and Amherst embassies had begun to 'open the eyes of the world at large' to China, much remained 'hidden from view'. The writer concluded, 'we plainly see that the inhabitants of the celestial empire are neither so great, so wise, or so powerful' as their eulogists have claimed (Yen Kwang to the editor, The Asiatic Review, January 1818, vol. 5, p. 4).

British readers were disappointed, however, that Ellis's (1817) book contained little new information or insight on China. The track from Peking to Canton, Barrow complained in his review in the Quarterly Review, was as earlier noted, 'nearly as well known as the road from London to Edinburgh' (1817a, p. 465). Although the Amherst Embassy had deviated from Macartney's route and travelled via Nanjing, 'the sameness, which is characteristic of China, seems everywhere to have occurred in the constant repetition of the same kind of objects' (p. 465). While the members of the Amherst Embassy took advantage of their opportunities to explore the Chinese countryside, these excursions had failed to produce any new knowledge of China. British rambles covered only a narrow range of terrain radiating from the boats where social contact was limited to peasant farmers, shopkeepers and temple priests. Crowds restricted any serious exploration of Chinese cities encountered en route and entry into Peking did not occur. Contact with Chinese women and insight into Chinese domestic life remained inaccessible. Barrow (1819) reminded his readers:

We should always remember that we view the Chinese character only as drawn by foreigners, who, from the nature of the government, have at all times been the objects of suspicion, and who hold a very limited intercourse with the natives. (p. 76)

China's persistent refusal to communicate with the outside world was summed up by the Eclectic Review in 1821:

We are completely shut out from personal communication with [the Chinese], being merely permitted to peep at them from Canton or Macao, as through a grate, where our Factory converse with them through the medium of a mercantile jargon, intelligible only to themselves and the individuals with whom they traffic. (vol. xvi, p. 37) 
The most noteworthy outcome affecting British perceptions of China from the accounts of the embassy was a revised assessment of the Qing emperor and his ministers. Accounts of the Macartney Embassy had portrayed the Qianlong emperor as a venerable old gentleman-statesman who was healthy, vigorous, affable and pragmatic, and who had received the British with graciousness and politeness. The Qianlong emperor had, at least, engaged with the British personally, exemplified famously by his brief conversation with the young Staunton, which signified an interest in the outside world. ${ }^{4}$ The Jiaqing emperor's reputation, on the other hand, based on his treatment of Amherst, whereby the ambassador was not even received, was judged by British popular journals in the most vitriolic of terms. At best, the emperor was 'a weak and capricious ruler, little acquainted with the affairs of government, or the condition of his people' (Barrow, 1819, p. 75)..$^{5}$ At worst, he was 'a man of impetuous and capricious disposition, increased by a habit of constant inebriation' (The Times, 26 August 1817). ${ }^{6}$ An official report on the state of China presented to the British Government in 1847 summed up the Jiaqing emperor's legacy: 'His life and reign is blank, as no just, noble, or generous action can be discovered' (Martin, 1847, p. 285). Modern historiography has revealed, on the contrary, that the Jiaqing emperor was pragmatic, sober, frugal, energetic and intent on instigating a series of new reforms in his reign (see Rowe, 2011; Wang, 2014). He was challenged not only with curbing the financial excesses of his father that had left the imperial coffers in a depleted state, but also by serious internal insurrections, assassination attempts and a serious pirate problem on the southern China coast (Wang, 2014, p. 128). His treatment of Amherst, however, served to define and denigrate the office of the Chinese emperor as a caricature of an oriental potentate in the British imagination. The emperor's ministers fared no better. China's despotic government was revealed to British readers as one characterised by 'childish vanity', insolence, meanness and 'unblushing falsehoods' (Barrow, 1817a, p. 465). Chinese mandarins, according to Ellis (1817), were arrogant, pretentious, rude, devious and liars. British reviewers were outraged by the Chinese suggestion at Tongzhou that Amherst perform the kowtow in private but was free to lie in making a false report to the king. Barrow, writing again in the Quarterly Review,

\footnotetext{
4 The interest or otherwise of Qing emperors in the 'outer world' was noted by Will (2008, p. 125).

5 Abel (1818) also described the Jiaqing emperor as 'a timid' man with a 'vacillating temper, sufficiently proved by his conduct to the British Embassy' (p. 118).

6 This comment was subsequently reprinted in the Gentleman's Magazine (July-December 1817, p. 231).
} 
wrote that this proposition 'affords no bad illustration of the notions of the Chinese respecting the conduct of men in public situations' (1817a, p. 470).

Not surprisingly, British reviewers vilified Heshitai in particular who was portrayed as arrogant, rude and lacking in any sense of propriety. His suggestion to Amherst that he was prepared to 'be his friend' at Peking if Amherst agreed to kowtow was seen as an attempt to pressure, if not blackmail, the British into complying with the ceremony. Significantly, it was after this meeting that Amherst made his final decision not to perform the kowtow based on Staunton's advice, as well as his own judgement as to the best course of action available to him. Heshitai's subsequent report to the Jiaqing emperor, sent from Tongzhou confirming that the 'English tribute-bearer is daily practising the ceremony, and manifests the highest possible respect and veneration' ('Heshitai's Report from Tongzhou to the Emperor' in Ellis, 1817, p. 509, Appendix 13), exemplified for Barrow (1817a) 'the utter disregard of the Chinese for the truth, from the emperor on the throne to the lowest of his minsters' (p. 472). Heshitai's rude behaviour at Yuanmingyuan of grabbing Amherst's arm still angered the British many years after the event. A review in the Asiatic Journal and Monthly Register for British India and Its Dependencies of an account of the recent Russian embassy to Peking in 1820-1821 thought it relevant and appropriate to refer to the Amherst Embassy where Heshitai's act of:

taking his Lordship [Amherst] by the arm in order to conduct him to another apartment, was nothing less than a brutal attempt to drag him into the presence chamber, where he would most probably have been compelled to undergo other humiliations. (Review of 'Travels of the Russian Mission through Mongolia to China, 1820-21' by George Timkowski, Asiatic Journal and Monthly Register for British India and Its Dependencies, 1827, p. 826)

Heshitai's behaviour, according to Peter Auber's account of China published in 1834, represented the 'most singular specimen of inhospitable and unmanly treatment' befitting the barbarity of a Tartar camp more than any 'which could have been expected even from the most uncivilised of crowned heads' (p. 263). The Pocket Magazine, which catered for a poorer educated clientele, was also scathing of Heshitai's insult to the representative of the British sovereign, describing it as a 'disgusting nonsense; insisting on the superior dignity of his Emperor over our King' (1818, vol. 1, p. 111). Amherst, the magazine concluded, would have been 
well within his rights to have thrown the insolent 'Ho [Heshitai] and Mu [Muketenge]' into the Baihe River (p. 110). The Chinese belief of there being 'only one sun in the firmament, so there was only one sovereign in the universe, the Emperor of the Heavenly Empire' was, in Auber's (1834, p. 261) opinion, absurd. The only interesting part of Ellis's (1817) account, The Times (8-9 October 1817) concluded, was that which:

describes the Ambassador in some danger of being introduced into the presence of the Emperor of China in the same manner as an unwilling creditor would be introduced into a sponging-house by a couple of bailiffs.

Conversely, the Edinburgh Review presented a contrarian view of the Amherst Embassy's reception in its review of Ellis's (1817) book. The Chinese Government's right to deny entry into their country of restless, ambitious and intriguing European visitors 'who have played the game of war and ambition, for near three hundred years, in their immediate vicinity' of India was acknowledged (Edinburgh Review, 1818, vol. 29, p. 29). Amherst, described as a nobleman of the 'most amiable character', had in fact little diplomatic experience and was assisted by a man-namely, Staunton-who was 'considered by the Chinese as a dangerous person'. Amherst had been poorly briefed on his mission and many in England were 'prepared for the catastrophe of the Embassy', especially following the fate of the Golovkin Embassy. The kowtow, in the Review's opinion, was no more humiliating than other court ceremony, and it was reasonable to expect that an ambassador visiting a foreign court should subscribe to local ceremonies and not 'attempt to prescribe a new one' (p. 29).

Although British public interest in the Amherst Embassy subsided after the appearance of the first accounts in 1817 and 1818, reference to it resurfaced throughout the following 20 years. Two books on China, it has been noted, were published in 1821. Reviews of Morrison's (1820) memoir of the embassy focused on the 'senseless state of idolatry' and superstition in China and the decay of its temples (see e.g. The Eclectic Review, 1821, vol. 16, pp. 569-571). The second book, mentioned previously, was Staunton's (1821) translation of Narrative of the Chinese embassy to the Khan of the Tourgouth Tartars in 1717. Its publication presented Barrow with yet another opportunity to voice his opinion on China through a review in the Quarterly Review. The Chinese, Barrow (1821) concluded, were a shrewd and ingenious people, excelling in the 
arts, manufacturing, agriculture, civil polity, literature and morals, and were indisputably far superior to other Asiatic peoples (pp. 414-415). But their condition suffered from a bad government and a terrible religion: 'the one, we think, renders them selfish and distrustful; the other superstitious and hypocritical' (p. 415). Chinese society had been made 'cold and repulsive' due to its exclusion of women shut behind family compound walls (p. 415). While Barrow thought a 'closer intimacy' with the Chinese people 'might incline us to entertain a somewhat more favourable opinion of them', this opportunity was prevented by government policy that was 'hostile to all international connections' and the difficult Chinese language prohibiting any communication with foreigners (p. 415). A final assessment of the emperor reflected the impact of the Amherst Embassy. The Qing emperor, in Barrow's opinion, was not a despot, but was little more 'than a puppet in the hands of a few great officers' (p. 415). Staunton's translation revealed further that the true status of a foreign mission 'in Chinese eyes' was one that was 'so little desirable' (p. 420).

\section{The Legacy of the Amherst Embassy in the Period Leading to Free Trade}

In 1821, an enquiry of the Select Committee of the House of Lords, initiated in part due to the current viceroy stopping trade at Canton, sought to investigate avenues for trade concessions in China. Reference was made to diplomacy's failure to secure positive outcomes:
All the efforts of the Company since the splendid Embassy of Lord Macartney from the King of Great Britain, could not procure the liberty of a second port; and so things continue to this day. Another recent Embassy from the sovereign of this country, intended also to procure ameliorations in the trade, was not even admitted into the emperor's presence. (Charles Grant as quoted in Report [relative to the trade with the East Indies and China] from the Select Committee of the House of Lords, 11 April 1821, p. 165)

The insolvency of the Hong merchants, through whom the British conducted their trade, resulted in a serious dispute at Canton in 1829. The viceroy had refused to discuss the issue with the Select Committee, which threatened to withdraw the Company ships to Manila as well as 
sending in the Royal Navy in an attempt to secure a dialogue. The viceroy eventually backed down and agreed to new concessions at Canton, including the appointment of three new Hong merchants.

The Select Committee's firm and decisive action in the face of Chinese intimidation at this time was a direct legacy of Staunton's resolute stand both at Canton in 1814 and during the Amherst Embassy where British submission was thought only to aggravate and promote Chinese demands. A further legacy of the Amherst Embassy, and arguably the major one, was the British recognition of the value of military force in assisting the procurement of British concessions from the Chinese Government. Captain Maxwell's success in silencing the Bocca Tigris forts and forcing his way up the Pearl River had broken the serious stalemate over the loading of teas on board the General Hewitt in 1816, and had resulted in the viceroy ameliorating his hostile stance towards the British by insisting that the shots fired at the Alceste were intended as a salute rather than an aggressive act. British views on dealing with China arguably changed as a result of Maxwell's action, reflecting the efficiency of enlisting British power to achieve national objectives. The former president of the Select Committee, Charles Marjoribanks, informed the president of the Board of Control, Charles Grant, ${ }^{7}$ in 1833 that diplomacy had failed in China and recommended:

Commissioners be sent, accompanied by a part of the naval squadron in India; for to command the slightest attention or respect in China, you must appear with an appropriate force; let your requisitions be such as you are justified in making, and be prepared to insist upon them if refused. This may be readily done by occupying ... one of the numerous islands in the Canton river, and, if necessary, seizing the forts which command its entrance. They have no force, either military or naval, to oppose to you, that is not contemptible. Under such circumstances I feel satisfied your demands would be granted in a very brief period. (Marjoribanks, 1833, p. 53)

Ellis and Staunton were also called on to give their views on the extension of the Company's charter in 1833. At issue was the question of maintaining the Company's tea monopoly in China in the face of growing pressure from British public opinion and manufacturers who

7 Charles Grant, later Lord Glenelg, was the son of the former chairman of the East India Company of the same name. 
petitioned the government for opening up the China trade to all traders. Ellis presented a series of letters on the East India question to members of the two Houses of Parliament in 1830 in which he addressed the major question: 'In what manner can the trade with China be carried on with most advantage to the English nation?' (Ellis, 1830, p. 26). His answer reflected views consolidated at the time of the Amherst Embassy. The Chinese Government, he argued, had 'peculiar opinions' regarding any contact with foreigners who were considered a danger to national security and a threat to Chinese morals and political and domestic harmony. China's great internal trade, observed by him during his travels with the embassy, meant they had no need for commerce with other nations (p. 29). ${ }^{8}$ Their trade with Britain was not founded on treaties between independent states but was solely in the hands of the Hong merchants who, in turn, were responsible for their dues to the Chinese Government. Ellis argued that, regardless of any change the British might make to the Company monopoly, the Hong merchants would retain their monopoly. Private traders, acting in an individual capacity in contrast to the powerful Select Committee, would be powerless to bargain with them, and control would soon fall into the hands of the more prosperous Hong merchants who would manipulate prices and the trade to their own advantage (p. 33). Diplomatic representation at Canton, in Ellis's view, was also useless. The presence of an American Consul had made no difference to the conduct of American private trade, whereas:

The power possessed by the Company's supercargoes of stopping the whole British trade ... has been found to be infinitely more calculated to prevent fresh exaction, than any diplomatic proceeding whatsoever, when addressed to a government so totally different, from the rest of the civilised world, in the laws and usages regulating international intercourse. (pp. 40-41)

Staunton held similar views. ${ }^{9}$ He addressed the House of Commons on 13 June 1833 with a series of recommendations during the debate on the renewal of the Company's charter. The valuable tea trade still contributed almost $£ 4$ million annually into the British Treasury's coffers, he reminded

8 Davis also believed that free trade with China was 'fraught with great evil' that would result in the rise of tea prices and a degradation in tea quality (see East-India Committee, The Times, 24 February 1830 , p. 3).

9 Staunton was elected first to the House of Commons as MP for the rotten boroughs of St Michael's in Cornwall and Heytesbury in Wiltshire between 1818 and 1833 (Staunton, 1856, p. 76). He was later elected as MP for Portsmouth. For a full examination of Staunton's career during this time, see Eastberg (2009, pp. 206-223). 
the House, but was governed solely by the arbitrary control of Chinese local authorities at Canton and subject to severe and vexatious restrictions (Staunton, 1840, Appendix, p. i). Company agents, acting as a powerful united group, were able to oppose the arbitrary and oppressive acts of the local government, which was not possible by individuals acting alone. Such influence was the 'sole check operating to control and counteract the corrupt local administrators of the peculiarly arbitrary and despotic government'. Staunton, unlike Ellis, still believed that diplomacy had a role to play in gaining trade concessions:

Notwithstanding the failure of all complimentary embassies to the court of Pekin, however otherwise beneficial in raising and procuring the due recognition of the national character, [Chinese] treaties with Russia prove there are no insurmountable obstacles to such an agreement. (p. ii)

The Charter for the East India Company was renewed in 1833 for another 20 years. The old title of governor-general of Bengal was changed to governor-general of India and the position of 'Chief Superintendent of Trade' in Canton replaced president of the Select Committee. ${ }^{10}$ Significantly, the China trade was opened to all (Mersey, 1949, p. 53). Staunton's views on how to deal with the Qing Government changed in 1840 , largely in response to the Chinese seizure and destruction of British property, consisting of opium valued at $£ 2$ million, at Canton (Eastberg, 2009, p. 221). Staunton asked the following question in an address to Parliament on the eve of the First Opium War: 'Is the contest in which we appear to be on the eve of embarking with the Emperor of China, a just and necessary war, or an act of cruel and iniquitous aggression?' (Staunton, 1840, p. 5). He still preferred a diplomatic solution for reestablishing British trade in China on a satisfactory and secure footing, but had reluctantly reached the conclusion:

that the context in which we are about to engage with China is perfectly just ... I rejoice to see that it has received this night the tacit approbation, at least, of the House. (p. 7)

While Staunton abhorred the opium trade and wished to see it abolished, he felt the current conflict was not about opium, but rather that the Chinese Government had breached international law in seizing British

10 Lord William Napier was the first appointed to this position, but his credentials were rejected by the viceroy of Canton when Napier arrived in 1834 (see Lovell, 2011, p. 6). 
property and had broken their trust of safely protecting the trade and British citizens (Eastberg, 2009, p. 221). Asked how he would have responded to Commissioner Lin Zexu's actions at Canton in confiscating British opium, Staunton told Parliament:

I must beg to tell ... the House what I did do when I was in Pekin with Lord Amherst, and under somewhat similar circumstances. When threatened in a similar manner by the Commissioner's Imperial Master himself, because I refused to advise my noble colleague to perform the Chinese ceremony, I neither trembled nor obeyed; and all the world knows that that Embassy was not only allowed to return safety [sic], but traversed the whole Chinese Empire afterwards with greater convenience and equal honors to the preceding Embassy of Lord Macartney. (p. 20)

Eastberg (2009, p. 223) has argued, convincingly, that Staunton's views on China were largely outdated and overtaken by events by the time of the First Opium War. Western perceptions of China had consolidated. Pertinently, Miller wrote in the context of some American opinion, which is applicable also to British views, that China's defeat in the Opium War was hardly a surprise given earlier reports of its military backwardness. He added:

The Amherst mission and the action of Captain Maxwell in Canton provoked one [American] editor in 1818 to declare that the country 'slumbers, like a drowsy and emasculate Mammoth ... till invasion, from the East and West shall enter her realms, and with fire and sword, purge away the gross and stagnant humors that clog her distempered frame'. (American Monthly Magazine and Critical Review, 1818, vol. II, p. 443 as quoted in Miller, 1974, p. 92)

Western abhorrence of the kowtow had become inextricably linked with Chinese identity and cultural imperatives in the Western imagination. John Quincy Adams, a former United States president and diplomat, wrote at the time of the First Opium War that its cause was not opium but the kowtow, blaming:

The arrogant and insupportable pretensions of China, that she would hold commercial intercourse with the rest of mankind, not upon terms of equal reciprocity, but upon the insulting and degrading form of relations between lord and vassal. (as quoted in Blusse, 2008, p. 88) 
This text is taken from Britain's Second Embassy to China: Lord Amherst's 'Special Mission' to the Jiaqing Emperor in 1816, by Caroline Stevenson, published 2021 by ANU Press, The Australian National University,

Canberra, Australia.

doi.org/10.22459/BSEC.2020.11 